\title{
ROLA PERSONELU MEDYCZNEGO WE WSPARCIU PSYCHICZNYM KOBIETY I JEJ RODZINY PO PRZEBYTYM PORONIENIU
}

\author{
THE ROLE OF MEDICAL PERSONNEL IN SUPPORT OF MENTAL HEALTH OF WOMEN WITH \\ A HISTORY OF MISCARRIAGE AND THEIR FAMILIES
}

Magdalena Napiórkowska-Orkisz, Jolanta Olszewska

DOI: https://doi.org/10.20883/pielpol.2017.72

\section{STRESZCZENIE}

Celem pracy jest ukazanie, jak ważną rolę w aspekcie psychicznym i moralno-etycznym odgrywa personel medyczny we wsparciu kobiety i jej rodziny po przebytym poronieniu.

Poronienie jest najczęstszym problemem prokreacji. Problem ten należy rozpatrywać nie tylko w aspekcie medycznym, ale także społecznym, rodzinnym i psychologicznym. Można mówić o zjawisku żałoby spowodowanej śmiercią bliskiej osoby. W konsekwencji nieprzebytej żałoby lub jej przedłużania może dojść do niewłaściwych zachowań interpersonalnych lub zaburzeń psychicznych (depresja, zespoły lękowe, zespół stresu pourazowego). Podstawowym elementem wsparcia psychicznego kobiety po przebytym poronieniu jest akceptacja jej uczuć, zezwolenie na wyrażanie negatywnych emocji, zapewnienie możliwości kontaktu z osobami najbliższymi. Zarówno personel medyczny, jak i rodzina, wspierając kobietę, często zapominają o ojcu dziecka. Mężczyzna również czuje się osamotniony w swej tragedii. Zamyka swój smutek w sobie. Nieokazywanie uczuć pogłębia depresję. Jeśli kobieta przeżywająca dramat poronienia ma już dzieci, personel powinien w swej opiece pamiętać i o nich. Dziecku należy wytłumaczyć, że poronienie nie jest niczyją winą. Personel medyczny odgrywa ważną rolę w procesie wsparcia psychicznego kobiety i jej rodziny po stracie dziecka.

Profesjonalizm, doświadczenie, wiedza i umiejętność komunikacji interpersonalnej są niezbędne $w$ dążeniu do realizacji takich celów, jak: pomoc w pogodzeniu się ze stratą, zezwolenie na doświadczanie cierpienia i żalu, pomoc w zaakceptowaniu rzeczywistości i życia bez dziecka, mobilizacja do inwestowania energii i uczuć w nowe relacje i związki. Pomocne personelowi medycznemu mogą okazać się kursy i szkolenia z postępowania w przypadku niepowodzenia położniczego. Powinny one uczyć umiejętnej współpracy z pacjentem przeżywającym stratę dziecka.

SŁOWA KLUCZOWE: poronienie, żałoba, ciąża, wsparcie psychiczne.

\begin{abstract}
The aim of this study is to show how important the role of medical staff in mental and moral-ethical terms is in support of women and with a history of miscarriage and their families.

Miscarriage is the most common problem of procreation. This problem should be considered not only in the medical aspect but also the social, family and psychological ones. You can talk about the phenomenon of mourning due to the death of a loved one. A consequence of unexperienced mourning, or its renewal may be inappropriate interpersonal behavior or mental disorders (depression, anxiety syndromes, and post-traumatic stress disorder). The basic element of psychological support of women with a history of miscarriage is the acceptance of her feelings, permission to express negative emotions, providing the possibility of contact with the closest people. Both medical staff and family supporting women often forget about the child's father. The man also feels alone in their tragedy. He closes his sadness in himself. If a woman experiencing a miscarriage drama has children, staff should remember about them. The child should be explained that abortion is not anyone's fault. Medical staff plays an important role in the psychological support of women and their families after the loss of a child.

Professionalism, experience, knowledge and skills of interpersonal communication are necessary in pursuit of purposes such as helping in coming to terms with the loss, allowing to experience suffering and sorrow, helping in accepting reality and life without a child, mobilization to invest energy and feelings in new relationships. Courses and training that concern dealing with the failure of maternity, may appear helpful for the medical personnel. They should teach skillful cooperation with the patient experiencing the loss of a child.
\end{abstract}

KEYWORDS: abortion, bereavement, pregnancy, psychological support. 


\section{Definicja, epidemiologia i przyczyny poronień}

Poronienie jest to wydalenie $z$ macicy obumarłego zarodka o wadze niższej niż 500 gram, do 22. tygodnia trwania ciąży [1]. Poronienia dzielimy na: zagrażające, w toku, zatrzymane, niezupełne, septyczne, zupełne i nawykowe. Poronienie zagrażające objawia się bezbolesnym krwawieniem z macicy i niewielką czynnością skurczową. Należy leczyć je zachowawczo. W przypadku wzmożenia objawów rokowanie dla ciąży jest niekorzystne. Poronienie w toku rozpoznawane jest w przypadku pęknięcia błon płodowych, przed 22. tygodniem ciąży. Postępowaniem z wyboru jest wyłyżeczkowanie jamy macicy. Poronienie, po którym nie nastąpiło wydalenie obumarłego płodu w okresie 8 tygodni, to poronienie zatrzymane. Konieczna jest indukcja porodu. Jeśli w jamie macicy pozostały resztki utkania łożyskowego, mamy do czynienia z poronieniem niezupełnym. Poronienie septyczne przebiega z wykładnikami stanu zapalnego narządu rodnego. Poronienie zupełne to poronienie, $w$ którym wydaleniu z jamy macicy uległo całe jajo płodowe [2, 3]. Znaczna część poronień, zwłaszcza zarodkowych (do 10. tygodnia ciąży), nie jest rozpoznawana. Często sama ciężarna traktuje poronienie jako spóźnione krwawienie miesiączkowe. Z powodu niepewnych danych statystycznych odsetek poronień jest trudny do oceny. Pewne jest, że poronienie dotyka dużej części par starających się o potomstwo. Jest to powszechny dramat [4]. Aż 25\% wszystkich kobiet, które zaszły w ciążę, utraciły ją na drodze poronienia. Około $15 \%$ zdiagnozowanych ciąż ulega poronieniu samoistnemu, w tym $1-2 \%$ to poronienia nawykowe. Badania dowiodły, że 0,4 \% kobiet doświadczyło trzech kolejno następujących po sobie poronień. Połowa poronień to poronienia występujące przed zagnieżdżeniem się zarodka w jamie macicy. Po 8. tygodniu ciąży ryzyko poronienia znacznie maleje i wynosi $10 \%-3 \%$ [5].

W trudnych momentach życia człowiek często zadaje sobie pytanie „Dlaczego?”. Naturalną potrzebą par, które dotknęła tragedia poronienia, jest chęć poznania jego przyczyny. Poronienie zazwyczaj spowodowane jest przez kilka czynników. W przypadku poronień samoistnych przyczyny ze strony kobiety obejmują $20 \%$, ze strony płodu i łożyska - $50 \%$, zaś ponad $10 \%$ to czynniki immunologiczne. Pozostałe to zewnętrzne czynniki uszkadzające jajo płodowe, czynniki psychiczne i przyczyny ze strony ojca [6, 7]. Rozpoznanie tych czynników jest bardzo trudne, szczególnie we wczesnej ciąży. Stąd ich częstość jest dla medycyny ciągłą zagadką, która nie została dokładnie zbadana [1].

Poronienie nawykowe (łac. abortus habitualis) diagnozowane jest, kiedy występują trzy lub więcej poronień po sobie. Najczęściej jest spowodowane zabu- rzeniami chromosomalnymi. Po wyłyżeczkowaniu jamy macicy materiał należy poddać badaniu histopatologicznemu w celu zdiagnozowania przyczyny poronienia. Zachęca się rodziców do badań genetycznych ich kariotypu. Niezależnie od przyczyny poprzednich poronień każda następna ciąża powinna być objęta szczególną opieką [8].

\section{Psychologiczny aspekt poronień}

Ciąża jest złożonym zjawiskiem i obejmuje zarówno procesy morfologiczne, fizjologiczne, jak i psychologiczne. W początkowym okresie kobieta uświadamia sobie realność istnienia dziecka oraz jego akceptacji zarówno w swoim ciele, które od teraz dzieli wraz z nim, jak i wśród rodziny, której staje się członkiem. Uwaga kobiety z dnia na dzień w coraz większym stopniu odbiega od niej samej i koncentruje się na dziecku, które nosi pod swym sercem.

Poronienie jest najczęstszym spotykanym problemem prokreacji. Stanowi jedną z przyczyn niemożności donoszenia ciąży i urodzenia zdrowego dziecka. Dlatego też problem ten należy rozpatrywać nie tylko w aspekcie medycznym, ale także społecznym, rodzinnym i przede wszystkim psychologicznym [5]. Badania dowiodły, iż poronienie jest na tyle przeżyciem traumatycznym, bolesnym dla kobiety i jej bliskich, że można mówić przy nim o zjawisku żałoby spowodowanej śmiercią bliskiej osoby. Żałoba jest to złożony proces opłakiwania śmierci bliskiej osoby i powolnego godzenia się z tym faktem. To proces indywidualny i zależy od szeregu czynników [9]. W piśmiennictwie często spotykamy się z opisem reakcji na bolesne doświadczenie obejmujących trzy fazy:

- fazy wstrząsu/szoku i negacji,

- fazy dezorganizacji/wycofania,

- $\quad$ fazy reorganizacji/akomodacji [9-11].

Zazwyczaj kobieta jest bardzo zaskoczona utratą dziecka. Ta niespodziewana tragedia prowadzi do szoku i niedowierzania. Kobieta pragnie uciec od wszelkich informacji. Wybucha płaczem i złością, zaprzecza faktom. Dominują w niej smutek, żal, niepokój i bezradność. Czuje się niespełniona, bez wartości. Obniża swą samoocenę. Obarcza się odpowiedzialnością za zaistniałą sytuację. Szuka winy w sobie. Może odczuwać gniew wobec personelu medycznego, swej rodziny czy samego dziecka [9]. Faza szoku charakteryzuje się reakcjami, które obserwator zaliczyłby do niewłaściwych. Kobieta może np. wybuchnąć szczerym śmiechem, który nie jest adekwatny do sytuacji. Po otępieniu emocjonalnym odczuwa tęsknotę, intensywnie snuje wyobrażenia, że płód wciąż żyje. Po czym zaczyna uświadamiać sobie stratę dziecka. Pogodzenie się ze stratą przynosi rozpacz lub depresję. Kolejno kobieta 
zaczyna chronić siebie i wycofywać się. Ostatnia faza polega na powracaniu do zdrowia, aż do odnowy. Jest to reorganizacja - odnalezienie nowego sensu życia i zmiana jego trybu [9].

Żałoba jest procesem złożonym i dynamicznym, dlatego trudno określić długość jej trwania. Jest ona zależna od wielu czynników: wcześniejsze doświadczenie utraty, pragnienie posiadania dziecka, posiadanie potomstwa, trudności w zajściu w ciążę, wsparcie społeczne, środowisko, wsparcie rodzinne, osobowość kobiety czy wiek rodziców. Piśmiennictwo ocenia ten czas na 12-18 miesięcy. Jest to okres cierpienia, niezrealizowanych planów, marzeń i odpowiedzi na nurtujące pytania. Patologia procesu żałoby ujawnia się w dwóch stadiach. Pierwsze z nich to przedłużająca się żałoba, niepogodzenie się z rzeczywistością mimo upływu czasu. Bądź przeciwnie - zablokowanie procesu żałoby, jej opóźnienie lub przerwanie. W konsekwencji nieprzebytej żałoby lub jej przedłużania może dojść do niewłaściwych zachowań interpersonalnych, zaburzeń psychicznych, takich jak: depresja, zespoły lękowe, a także zespół stresu pourazowego. Szacuje się, że zaburzenia depresyjne występują u $10 \%$ do $48 \%$ kobiet. Ryzyko zwiększa się w przypadku przebytych już depresji, nieposiadania jeszcze potomstwa, kolejnego poronienia czy braku wsparcia społecznego. Pozostawienie pamiątek po dziecku (fotografii USG), a także pochówek powodują urealnienie osoby dziecka i pozytywnie wpływają na proces żałoby. Jednak w przypadku poronień często niestety brakuje jakichkolwiek dowodów życia i śmierci dziecka [4]. Oprócz braku pamiątek, w przypadku poronień zarodkowych, problemem również okazuje się niewiedza personelu medycznego na temat pozytywnych rezultatów przekazywania pamiątek rodzinie zmarłego dziecka.

Przeprowadzono badania ankietowe, w których jednym z badanych aspektów było poznanie postaw lekarzy wobec przekazywania rodzicom pamiątek po zmarłym dziecku. Odpowiedzi są zaskakujące. Aż $87 \%$ respondentów stwierdziło, że nie ma potrzeby, a nawet sensu przekazywać takie pamiątki. Padają argumenty: „najlepszą metodą jest niepamięć”, „to tylko pogarsza problem". Tylko 7\% lekarzy przekazuje pamiątki po zmarłym dziecku [12].

Dla przebiegu okresu żałoby znaczącym faktem okazuje się to, czy utrata dziecka nastąpiła niespodziewanie, czy kobieta miała świadomość zagrożenia ciąży. W drugim przypadku obserwujemy zjawisko antycypacji żałoby - przeżywania jej przed zaistnieniem utraty. Taka sytuacja może niwelować intensywność traumy po poronieniu. Zwłaszcza gdy stwierdzono nieprawidłowości w rozwoju płodu. W przypadku oczekiwanej utraty proces żałoby może nastąpić przed śmiercią płodu. Rodzice stopniowo żegnają się z dzieckiem i przygotowują na jego stratę. Wpływa to pozytywnie na proces żałoby $[4,13]$.

Przy zagrożonej ciąży większość kobiet jest poddawana leczeniu. Kobieta rezygnuje $z$ wielu wygód na rzecz hospitalizacji czy reżimu łóżkowego. Zdarza się jednak, że mimo to ciąża kończy się niepowodzeniem. U ciężarnych budzi się poczucie niesprawiedliwości i złości. Podjęły wysiłek, by utrzymać ciążę, a ich starania nie opłaciły się. Kiedy raz dotknie nas tragedia, obawiamy się, że sytuacja ponownie się powtórzy. Konsekwencją utraty ciąży jest napięcie emocjonalne. Lęk o powodzenie kolejnej ciąży jest rzeczą naturalną. Osiąga on swój szczyt w tygodniu, w którym poprzednim razem doszło do poronienia. $Z$ upływem czasu matka i jej bliscy zaczynają wierzyć w powodzenie kolejnej ciąży. Towarzyszą im nadzieja i poczucie bezpieczeństwa [4]. Jeśli jednak po raz kolejny dojdzie do poronienia, przy następnej ciąży powstanie mechanizm obronny. Matka podświadomie stara się nie urealniać istnienia dziecka, nie wiązać się z nim uczuciowo. Nie snuje planów i marzeń związanych z macierzyństwem. Wyznaje zasadę - im mniej się zaangażuję, tym mniejsze będzie cierpienie po stracie dziecka. Kobieta skupia się na medycznych aspektach ciąży. Zaczyna traktować ją jako zadanie do wykonania. Tłumi pozytywne emocje, nabiera dystansu do dziecka i stara się nie tworzyć z nim głębszych relacji. Pragnie w ten sposób uchronić się od rozczarowania. Psychologiczne następstwa poronienia mogą rzutować na kolejne decyzje prokreacyjne, jakość nawiązywania więzi z dzieckiem, a także na sposób wychowywania potomstwa [14, 15].

Murlikiewicz i Sieroszewski przeprowadzili badanie, którego celem było przedstawienie występowania podwyższonego poziomu lęku, objawów depresji oraz stresu pourazowego z powodu poronienia samoistnego. Autorzy podjęli próbę odpowiedzenia na pytanie, czy istnieją różnice w nasileniu objawów depresji, poziomu lęku oraz stresu pourazowego w zależności od: wieku kobiet, ich wykształcenia, rodzaju związku, posiadania dzieci, tygodnia ciąży, w którym doszło do poronienia. W badaniu wzięło udział 40 kobiet w wieku 18-39 lat. Kobiety były hospitalizowane w Klinice Medycyny Płodu i Ginekologii Uniwersytetu Medycznego w Łodzi, w okresie 6 miesięcy (od stycznia do czerwca 2013 roku). Badania przeprowadzono w ciągu tygodnia od poronienia. Każdej z pacjentek zaproponowano opiekę psychologa. Badanie polegało na samodzielnym wypełnieniu ankiety, poprzez odpowiedź na pytania socjodemograficzne oraz rozwiązanie testów psychologicznych. Przeprowadzone badanie wykazało, że styl radzenia sobie ze stresem skoncentrowany na emocjach, lękowa osobowość i wcześniejsze doświad- 
czenie poronienia mogą być traktowane jako czynniki ryzyka depresji (3\%) i stresu pourazowego. Kobiety roniące o osobowości lękowej i stylu skoncentrowanym na emocjach są bardziej skłonne do obwiniania się za utratę ciąży i reagowania silniejszym stresem. Osobowość nacechowana otwartością na doświadczenia pozwala na lepszą adaptację w kryzysie [9] i predysponuje do bardziej optymistycznego patrzenia w przyszłość. Posiadanie takiego charakteru przyspiesza proces adaptacji. Prace badawcze nie wykazują istnienia bezpośredniej zależności między wiekiem kobiety a ryzykiem wystąpienia objawów zaburzeń depresyjnych i PTSD [14]. Reakcje kobiet roniących w tym samych tygodniu trwania ciąży wykazują duże zróżnicowanie [16]. Badacze podkreślają, że ochronny wpływ na kondycję psychiczną kobiety po poronieniu ma fakt posiadania dzieci. Badania dowodzą, iż kobiety z wykształceniem podstawowym i średnim charakteryzują się większym nasileniem objawów depresji niż pacjentki z wykształceniem wyższym [14].

\section{Personel medyczny jako wsparcie psychiczne}

Większość par odczuwa szczęście na wiadomość o ciąży. Z radością oczekują narodzin dziecka. Już w początkowym okresie mogą snuć plany o wspólnej przyszłości i na przykład wybierać imię dla maleństwa. Matka już od pierwszych dni stara się zbudować więź z dzieckiem: mówi do niego, wyobraża sobie, jak ono teraz wygląda, czyta literaturę obrazującą rozwój płodu. Poronienie jest bardzo bolesnym przeżyciem dla kobiety, jej partnera i najbliższej rodziny. Gdy dochodzi do tragedii, bardzo trudno jest komuś obcemu zrozumieć, co czują bezradni rodzice, szczególnie kiedy do poronienia dochodzi we wczesnej ciąży. Personel medyczny na co dzień spotyka się ze śmiercią. Poronieniem kończy się 25\% wszystkich ciąż. Ginekolodzy, położne narażeni są na ciągłe obserwacje niepowodzenia ciąż. Spotykają się z tą sytuacją tak często, że przygnębienie i smutek kobiety mogłyby być przez nich niezauważone, a poronienie mogliby zacząć traktować jako zjawisko powszechne, a nawet normalne. Profesjonalizm nie powinien na to pozwolić. Personel ma budzić zaufanie i dać pacjentkom poczucie bezpieczeństwa [9]. W celu nawiązania takiego kontaktu personel medyczny powinien pamiętać o przedstawieniu się i wyjaśnieniu swojej roli w opiece nad pacjentką. Powinien prezentować spokojną postawę, szanować prywatność i poczucie intymności pacjentki. Zawsze należy uzyskać zgodę kobiety na wykonanie wszelkich badań i zabiegów [17].

W oddziale, w którym nastąpił martwy poród lub zgon noworodka, położna wykonuje niezwłocznie toaletę ciała noworodka, zakłada na dwie kończyny identyfikatory z imieniem i nazwiskiem matki dziecka. Po pożegnaniu rodziców z dzieckiem położna zawija szczelnie ciało noworodka w dwie serwety. Oznakowuje je, pisząc na dokumencie: imię i nazwisko matki dziecka, datę urodzenia i płeć dziecka oraz informacje o pochówku. Po upływie 2 godzin od zgonu zwłoki należy przenieść do chłodni. Lekarz neonatolog informuje pielęgniarkę społeczną o zgonie dziecka. Pielęgniarka nawiązuje kontakt $z$ rodzicami i ustala z nimi czas i miejsce przekazania im zwłok dziecka. W pomieszczeniu, w którym zwłoki są przechowywane, zostają one przygotowane do pochówku. Przygotowanie to odbywa się zgodnie z wolą rodziców/osób uprawnionych do pochówku. Co najważniejsze - zwłoki dziecka traktowane są z należytym szacunkiem [18]. Jeżeli tylko jest to możliwe i rodzice wykazują chęć, powinno się im pokazać dziecko. Bez względu na niską wagę (kilkaset gramów), zniekształcone ciało. Należy ciało owinąć w kocyk czy pieluszkę i w godnych, ludzkich warunkach pokazać je rodzicom. Rodziców należy pozostawić samych i zapewnić im dowolną ilość czasu na pożegnanie [19].

Podstawowym elementem wsparcia psychicznego kobiety po przebytym poronieniu jest akceptacja jej uczuć, zezwolenie na wyrażanie negatywnych emocji i przeżywanie procesu żałoby. Bardzo pomocna jest rozmowa o tym, co się stało [9]. Przed wyjaśnieniem przyczyn niepowodzenia personel medyczny jest zobowiązany zapewnić pacjentce czas pozwalający na oswojenie się z zaistniałą sytuacją [17]. Pomieszczenie, w którym przeprowadzona zostaje rozmowa, powinno być odosobnione. Podczas przekazywania informacji o śmierci dziecka istotna jest obecność obojga rodziców. Badania dowodzą, iż stały kontakt z kimś bliskim może zmniejszyć negatywne uczucia [19]. Rozmowa ta jest bardzo trudna, jednak w procesie żałoby przynosi dobre efekty. Dlatego bardzo ważne jest, by lekarz, położna udzielili dokładnych informacji na temat tego, co się wydarzyło, co aktualnie się dzieje i jaka może być przyszłość. Ważne, by wspomnieć o przyczynach poronienia i wpływie tego wydarzenia na płodność. Wiedza ta pomaga zmniejszyć strach i zniwelować uczucie bezradności czy też winy. Należy poświęcić na tę rozmowę tyle czasu, ile pacjentka potrzebuje. Położna powinna zachęcać kobietę do zadawania pytań. Dzięki temu uświadamia sobie, jakie problemy są dla pacjentki najważniejsze. Położna, niczym przyjaciółka, zachęca słuchaczkę do wyrażania uczuć. Dzięki rozmowie zbiera wywiad, na podstawie którego poznaje problemy kobiety, a to ułatwi jej opiekę nad nią. Rozmowa powinna odbywać się bez pośpiechu, z życzliwością i szacunkiem. Dialog wspomaga powrót pacjentki do równowagi psychicznej. Pozwala zastano- 
wić się pacjentce nad tym, jak rozstrzygnąć dręczące ją dylematy. Na przykład, czy powinna uczestniczyć w pochówku, jak należy rozmawiać o stracie ze starszymi dziećmi. Niezrozumienie odczuć kobiety, bagatelizowanie problemu, brak kontaktu, intymności i akceptacji negatywnych uczuć kobiety mogą zaostrzyć przeżywaną przez nią rozpacz $[9,20]$.

Niestety, postawy, jakie prezentuje personel medyczny, nie zawsze mogą być wzorem do naśladowania. Niewłaściwe zachowania są tłumaczone: zbyt wielką liczbą pacjentek pod opieką, niedostateczną ilością czasu, zbyt dużym obciążeniem obowiązkami. Przyczyną jest również niewystarczająca wiedza na temat procesów psychicznych towarzyszących zjawisku żałoby i potrzeb kobiety pogrążonej w rozpaczy. Jednak należy pamiętać o tym, iż swoisty charakter zawodów medycznych to nie tylko wysoki poziom wiedzy medycznej, ale także znajomość psychologii oraz etyki [19].

Sytuacją, która potęguje stres po poronieniu, a czasem może stać się jeszcze gorszą traumą dla pacjentki, jest jej hospitalizacja w sali razem z ciężarnymi czy położnicami. Obraz dużego brzucha kobiety leżącej obok, świadczący o obecności tam zdrowego dziecka, odgłos bicia serca przy podłączeniu pacjentki do KTG czy też płacz narodzonego już dziecka potęgują w kobiecie smutek, żal, złość, bezradność, poczucie straty i winy. Dlatego należy takich sytuacji unikać $[9,17,20$, 21].

Bardzo ważną informacją, jaką lekarz powinien przekazać swojej pacjentce, jest to, iż od 2007 roku rodzice dzieci urodzonych martwo lub poronionych mają prawo dokonać pochówku. Nie jest to uzależnione od czasu trwania ciąży. Rodzice otrzymują akt urodzenia $z$ adnotacją o urodzeniu martwym. Z szacunku do poronionego dziecka należy się mu pochówek [20]. Zwykle rodzice nie otrzymują ciała dziecka. Jeśli zdecydują się na pochówek dziecka, w dokumentacji należy zaznaczyć płeć dziecka. Jeśli lekarz nie może stwierdzić płci, należy powiadomić rodziców o możliwości wykonania odpłatnego badania genetycznego [22]. Ponieważ jeszcze nie istnieje w Polsce specjalny obrzęd pogrzebu dzieci poronionych, stosowane są wybrane obrzędy dla dzieci nieochrzczonych. Ceremonia pochówku może odbyć się w domu, kościele czy na cmentarzu. Jeśli rodzice mają życzenie, mogą zamówić mszę świętą pogrzebową. Nie ma ona charakteru przebłagalnego za grzechy dziecka. Jest prośbą o pociechę i siłę dla rodziców. Obrzęd pochówku i msza święta pomagają pogodzić się ze śmiercią dziecka, a także dają rodzicom pewność, że pożegnali się z nim najszczerzej i najpiękniej, jak umieli. Zaoszczędzi im to wyrzutów sumienia w późniejszym okresie. Mogiła staje się miejscem, gdzie rodzina może odwiedzić dziecko, zapalić znicz.
Jest to szczególnie ważne dla rodzin wierzących. Drugą równie ważną informacją, której kobiety dość często zapominają zasięgnąć (pod wpływem stresu), jest to, że kobieta ma prawo do urlopu macierzyńskiego trwającego 8 tygodni oraz prawo do uzyskania zasiłku pogrzebowego [20].

Ważnym aspektem jest zapewnienie kobiecie możliwości kontaktu z osobami najbliższymi. Obecność partnera daje poczucie bezpieczeństwa, zmniejsza uczucie lęku. Kobieta po stracie dziecka czuje się osamotniona, dlatego ważne jest, by nie zostawała sama. Wspólne przeżywanie śmierci dziecka może przyczynić się do nawiązania bliższej więzi między partnerami [20]. Zasadniczym aspektem mającym na to wpływ jest jakość wcześniejszych relacji panujących w rodzinie. Jeśli panował w niej klimat pełen ciepła i miłości, rodzina powinna z czasem wyjść z kryzysu. Doświadczonych stratą dziecka rodziców łączą podobne uczucia i reakcje. Mimo to żałoba zawsze jest przeżyciem osobistym i indywidualnym [19]. Rodzinie należy udzielić informacji o możliwości uzyskania pomocy psychologicznej i organizacjach udzielających wsparcia osobom, które dotknęła podobna tragedia [17].

Należy pamiętać, że położna jako profesjonalistka w swej dziedzinie sprawuje opiekę nie tylko nad kobietą po poronieniu, ale również nad jej rodziną. Ojciec tak samo jak matka może odczuwać gniew, rozczarowanie, bezradność. Mężczyzna martwi się o zdrowie swej partnerki. Zastanawia się nad powodem poronienia i szuka winy w sobie. Obwinia się, że za mało pomagał w obowiązkach domowych, że nie zapewnił jej wystarczająco dużo czasu na odpoczynek. Zastanawia się nad wpływem swych być może niewłaściwych genów i swoim stylem życia. Czuje się do niczego nieprzydatny i może równie łatwo wpaść w depresję. Szczególnie że zarówno personel medyczny, jak i przyjaciele czy rodzina, wspierając kobietę, kierując na nią całą swą uwagę, często zapominają o ojcu dziecka. Mężczyzna czuje się osamotniony w swej tragedii. Chcąc być twardym, zamyka swój smutek w sobie. Nieokazywanie uczuć pogłębia depresję. Brak rozmowy między partnerami może przyczynić się do kolejnego nieszczęścia, którym jest rozpad związku. Poronienie niejednokrotnie jest pierwszym problemem, jaki napotyka młoda para [4, 9]. Przeżywanie żałoby po stracie ciąży może również skutkować pogorszeniem się relacji w kontekście kontaktów seksualnych [11]. Jeśli kobieta odczuwa, że partner jest niedostatecznie zaangażowany w bolesną sytuację, buduje ona przepaść pomiędzy sobą a nim - rośnie dystans. Po zakończeniu procesu żałoby dystans ten stanowi duży problem dla dalszej pomyślnej prokreacji. Personel medyczny powinien umieć zauważyć tę niepokojącą sytuację. I starać się pomóc poprzez uświa- 
damianie mężczyzny, że ma on prawo do odczuwania żalu i smutku, do wrażliwości. Uzmysłowić, że uczucia te nie pozbawiają go męskości, a wręcz przeciwnie są naturalne w obecnej sytuacji. Personel, nakłaniając mężczyznę do szczerej rozmowy z partnerką, nie tylko przynosi mu ulgę w samotnym cierpieniu, ale być może ratuje przyszłość jego związku. Dramatyczne przeżycie może zbliżyć dwoje ludzi. Niejednokrotnie wychodzą oni z kryzysu z większą miłością i podziwem dla siebie nawzajem [4, 9].

Jeśli kobieta przeżywająca dramat poronienia ma już dzieci, personel powinien w swej opiece pamiętać i o nich. Dziecko często nie rozumie do końca, co się wydarzyło, mimo to odczuwa smutek rodziców i dzieli go z nimi. Czuje się czasem osamotnione. Kiedy jest starsze, może szukać przyczyny poronienia w swoim zachowaniu. Obwinia się o to, że myślało o przyszłym członku rodziny z zazdrością, czy też o to, że za mało pomagało mamie lub za mocno uderzało $w$ brzuch podczas zabawy. Dziecku należy wytłumaczyć, że poronienie nie jest niczyją winą. Należy pamiętać, by w rozmowie z dzieckiem stosować wyrażenia i słowa dopasowane do jego wiedzy i wieku [9].

Personel medyczny odgrywa ogromnie ważną rolę w procesie wsparcia psychicznego kobiety i jej rodziny po stracie dziecka. Dobroć, życzliwość, otwartość, umiejętność słuchania i dobre słowo są niezbędnymi substratami do prawidłowego przejścia procesu żałoby. Profesjonalizm, doświadczenie, wiedza i umiejętność komunikacji interpersonalnej są niezbędne w dążeniu do realizacji takich celów, jak:

- $\quad$ pomoc w pogodzeniu się ze stratą,

- zezwolenie na doświadczanie cierpienia i żalu,

- $\quad$ pomoc w zaakceptowaniu rzeczywistości i życia bez dziecka,

- mobilizacja do inwestowania energii i uczuć w nowe relacje i związki,

- odzyskanie wiary $w$ to, że wciąż mają możliwość zostać szczęśliwymi rodzicami,

- pomoc w odzyskaniu równowagi, bio-psycho-społecznej kobiety i jej najbliższych [4].

Przykrym jest fakt, że pacjentki skarżą się na chłodny, naukowy i oficjalny stosunek personelu. Bardzo wyraźny jest brak przygotowania personelu medycznego do przeprowadzania rozmów z rodzinami w sytuacji poronienia. Często zespół medyczny przyjmuje postawę unikania kontaktu z pacjentką, zostawia bez odpowiedzi pytania pacjentki, ignoruje jej przeżycia. Najczęściej popełnianym błędem jest uprzedmiotowienie poronienia. Personel medyczny sprawia kobiecie przykrość, gdy używa sformułowań: „embrion”, „zarodek”, „płód”, „obumarcie”. Nie potrafi empatycznie powiedzieć: „straciła pani dziecko” lub „pani dziecko zmarło”.
Do najczęściej spotykanych nietrafionych pocieszeń należą:

- To był zaledwie 5./9./12. tydzień ciąży”. Zespół terapeutyczny często nie zdaje sobie sprawy, że z tak wczesną ciążą kobieta zdążyła się związać.

- „Będzie Pani miała wiele innych dzieci”. Nie można zastąpić jednego dziecka kolejnym.

- Nic takiego się nie stało, to się często zdarza”. Jest to bagatelizowanie zdarzenia. Porównywanie do innych rodzin nie łagodzi cierpienia.

- „Niech państwo postarają się zapomnieć". W procesie żałoby nie chodzi o to, by zapomnieć. Wręcz przeciwnie, takie zachowanie wpływa na zaburzenie procesu żałoby.

- „Należy się cieszyć, urodziłaby pani dziecko z wadami”. Personel, wypowiadając te słowa, myśli, że ułatwi pogodzenie się z sytuacją. Jest to mylne spostrzeżenie.

W sytuacji tak wielkiej tragedii, jaką jest strata dziecka, każde słowo wydaje się być zbyteczne. Ważne jest jednak, by powiedzieć: „mogę tylko sobie wyobrazić, jak musi być państwu ciężko w tej sytuacji”, „bardzo mi przykro z powodu śmierci pani dziecka". Należy pamiętać o takich prostych, lecz wymownych gestach [19].

\section{Dyskusja}

W latach 2003-2007 przeprowadzono badanie dotyczące problemu postaw lekarzy wobec pacjentki po niepowodzeniu położniczym, w tym poronieniu. Badaniami ankietowymi objęto 164 lekarzy ginekologów. Ankieta była anonimowa i zawierała 44 pytania. W odpowiedzi na pytanie o własne reakcje w sytuacji smutku pacjentki po stracie dziecka za najbardziej słuszną reakcję $64 \%$ uznało wspieranie pacjentki i niesienie ulgi, 23\% respondentów skupiło się tylko na pocieszaniu, niestety niekiedy z lekkim bagatelizowaniem, 11\% ginekologów opowiedziało się za profesjonalizmem medycznym. Skupiło się na udzielaniu rad, by pacjentka urodziła następne dziecko, lub na podaniu środka uspokajającego. W oczach pacjentki lekarz wypowiadający się w sposób „medyczny” jest odbierany jako nieczuły lub niezainteresowany jej przeżyciami [12]. Psycholodzy podkreślają, że należy wystrzegać się wypowiedzi: „nie martw się, następnym razem się uda”, „żadnego dziecka tam jeszcze nie było”, „nie zadręczaj się tym”, „jesteś jeszcze młoda, zdążysz urodzić i wychować drugie dziecko". Należy również unikać wypowiedzi, które obarczają pacjentkę winą: „gdyby pani wcześniej przyszła". Takie nieprzemyślane wypowiedzi świadczą o bagatelizowaniu sytuacji, zaprzeczają jej powadze. Przyczyniają się do nieprawidłowego proce- 
su żałoby, który w efekcie może prowadzić do poważnych zaburzeń psychicznych [9, 20].

Pytano lekarzy, w jaki sposób informują pacjentkę o diagnozie poronienia. W badanej grupie 16\% odpowiedziało, że każda sytuacja jest indywidualna, a 30\% respondentów odpowiedziało, że starają się informację przekazać ze zrozumieniem i jednoczesnym wsparciem pacjentki. Tylko 23\% lekarzy czuło się w tej roli profesjonalnie. Na udzielaniu informacji o wykonaniu niezbędnych badań diagnostycznych, ustalających przyczynę niepowodzenia położniczego, chcąc tym samym ukierunkować pacjentkę na przyszłość, skupiło się 19\% respondentów. Spośród badanych 8\% lekarzy przekonywało pacjentki o braku ich winy w tym, co się stało, nie zapominając o „zdejmowaniu” odpowiedzialności z siebie jako lekarza. Część lekarzy przyznała, że nie radzi sobie z problemem bądź unika jednoznacznej odpowiedzi na pytania pacjentki. Zdarzały się też osoby nieudzielające odpowiedzi z powodu braku doświadczenia. Zazwyczaj było to spowodowane wewnętrznymi ustaleniami szpitala, jak na przykład faktem, iż informacje przekazuje tylko ordynator. $Z$ badań wynika, że $72 \%$ lekarzy informuje o poronieniu osobiście. Jednak bliższa analiza wyników badań wykazała, że lekarze nie czują się przygotowani i kompetentni w tej trudnej sytuacji [12]. Należy więc zwrócić uwagę na ten problem. Pomocne lekarzom, szczególnie młodym i niedoświadczonym, mogłyby okazać się kursy i szkolenia z postępowania w przypadku niepowodzenia położniczego. Powinny one uczyć umiejętnej współpracy z pacjentem przeżywającym stratę dziecka. Dla położnych należy organizować kursy i spotkania, w czasie których mogłyby wyrażać własne uczucia wobec pacjentki w tej trudnej sytuacji [19]. Należy także prowadzić badania w tym zakresie, by wychwycić potrzeby i braki wiedzy psychologicznej, umiejętności interpersonalnych personelu medycznego. By móc, poprzez poszerzanie tej wiedzy, pozytywnie wpłynąć na jakość opieki nad kobietą i jej rodziną po poronieniu.

Co ciekawe, a jednocześnie naturalne - lekarze posiadający doświadczenie utraty dziecka przechodzą proces żałoby, straty tak jak rodzice, tylko z mniejszą intensywnością. Nie jest im obce uczucie bezradności i porażki [23]. Śmierć dziecka jest przeżywana jako niepowodzenie zawodowe, przegrana walka o życie [19]. Lekarze, którzy informowali pacjentkę osobiście, robili to z dużą empatią, wczuwając się w rolę kobiety, a jednocześnie odnosząc tę sytuację do siebie: „daję do zrozumienia, że dla mnie też jest to strata" [12]. Rozporządzenie Ministra Zdrowia z dnia 1 grudnia 2015 r. (...) wprowadza dokładnie określone standardy postępowań okołoporodowych w opiece nad pacjentkami w sytuacji niepowodzeń położniczych, w swej treści nie zapomina- jąc o personelu medycznym. Stanowi, że personelowi medycznemu zapewnia się wsparcie w radzeniu sobie ze stresem w związku z opieką nad kobietą i dzieckiem w sytuacji niepowodzenia położniczego [17].

\section{Piśmiennictwo}

1. Dębski R. Ginekologia kliniczna. Wrocław: Elsevier Urban \& Partner; 2009. 829.

2. Słomko Z (red.). Ginekologia. Warszawa: PZWL; 2008. 587.

3. Opala T. Ginekologia. Podręcznik dla położnych, pielęgniarek i fizjoterapeutów. Warszawa: PZWL; 2003. 159.

4. Bręborowicz GH. Ciąża wysokiego ryzyka. Poznań: Ośrodek Wydawnictw Naukowych; 2006. 1174-1181.

5. Bręborowicz GH. Położnictwo i ginekologia. T. 1. Warszawa: PZWL; 2005. 753-754.

6. Chazan B. Postępowanie w nagłych stanach w położnictwie i ginekologii, Warszawa: PZWL; 2002. 371-374.

7. Akolekar R, Bower S, Flack N, Bilardo CM, Nicolaides KH. Prediction of miscarriage and stillbirth at 11-13 weeks and the contribution of chorionic villus sampling. Prenat Diagn. 2011; 31(1): 38-45.

8. Szymański W (red.). Rudolfa Klimka położnictwo. Kraków: Dream; 1999. 376.

9. Makara-Studzińska M, Iwanowicz-Palus G. Psychologia w położnictwie i ginekologii, Warszawa: $P Z W L ; 2009$. 157-163.

10. Lipczyński A. Psychologiczna interwencja kryzysowa w sytuacjach kryzysowych. Warszawa: Difin; 2007. 100-120.

11. Bielan Z, Machaj A, Stankowska I. Psychoseksualne konsekwencje straty dziecka w okresie ciąży i porodu. Seksuol Pol. 2010; 8(1): 41-46.

12. Szymańska M. Postawa lekarza w sytuacji niepowodzenia położniczego - aspekt zachowaniowy. Perinatol Neonatol Ginekol. 2011; 4(2): 101-105.

13. Murlikiewicz M, Sieroszewski P. Poziom depresji, lęku i objawów zaburzenia po stresie pourazowym w następstwie poronienia samoistnego. Perinatol Neonatol Ginekol. 2013; 6 (2): 93-98.

14. Barton-Smoczyńska I. Adaptacja kobiet po śmierci dziecka poczętego. Poronienie. W: Klahs C (red.). Zrozumieć rodziców po stracie. Poznań: W drodze; 2010.

15. Łuczak-Wawrzyniak J, Czarnecka-Iwanczuk M, Bukowska A et al. Wczesne i późne psychologiczne skutki utraty ciąży. Ginekol Położ. 2010; 81: 374-377.

16. Murlikiewicz M, Sieroszewski P. Poziom depresji, lęku i objawów zaburzenia po stresie pourazowym w następstwie poronienia samoistnego. Perinatol Neonatol Ginekol. 2013; 6(2): 93-98.

17. Rozporządzenie Ministra Zdrowia z dnia 9 listopada 2015 r. w sprawie standardów postępowania medycznego przy udzielaniu świadczeń zdrowotnych w dziedzinie położnictwa i ginekologii z zakresu okołoporodowej opieki położniczoginekologicznej, sprawowanej nad kobietą w okresie ciąży, porodu, połogu, w przypadkach występowania określonych powikłań oraz opieki nad kobietą w sytuacji niepowodzeń położniczych. Dz.U. 2015 poz. 2007.

18. Rozporządzenie Ministra Zdrowia z dnia 7 grudnia 2001 r. w sprawie postępowania ze zwłokami i szczątkami ludzkimi. Dz.U. $2001 \mathrm{Nr}$ 153, poz. 1783.

19. Bubiak A, Bartnicki J, Knihnicka-Mercik Z. Psychologiczne aspekty utraty dziecka $w$ okresie prenatalnym. Piel Zdr Publ. 2014; 4(1): 69-78.

20. Jo A, Levy V, Roch S. Nowoczesne położnictwo. Opieka poporodowa. Warszawa: PZWL; 1995. 126-130. 
21. Sikora K. Reakcje kobiet po stracie ciąży oraz zachowania partnerów. Ginekol Położ. 2014; 9(3): 40-55.

22. Stadnicka SK, Bień A, Gdańska P, Piechowska J. Poronienie i ciąża obumarła w aspekcie prawa - udział położnej w opiece nad pacjentką w sytuacji utraty ciąży. J Educ Health Sport. 2016; 6(9): 379-390.

23. Peretz D. Development, object relationships, and loss. W: Shoenberg B, Carr AC, Peretz D, Kutscher AH (red.). Loss and grief: Psychological management in medical practice. New York: Columbia University Press; 1970. 3-19.
Artykuł przyjęty do redakcji: 27.09.2016

Artykuł przyjęty do publikacji: 25.01.2017

Źródło finansowania: Praca nie jest finansowana z żadnego źródła. Konflikt interesów: Autorzy deklarują brak konfliktu interesów.

\section{Adres do korespondencji:}

Magdalena Napiórkowska-Orkisz

Tułodziad 14

14-120 Dąbrówno

tel. kom.: 607107391

e-mail: naporkowska-orkisz@wp.pl 